\title{
Aligning Supply Chain Strategy with Product Life Cycle Stages
}

\author{
João Gilberto Mendes dos Reis, Sivanilza Teixeira Machado, \\ Pedro Luiz de Oliveira Costa Neto, and Irenilza de Alencar Nääs \\ Paulista University, Postgraduate Studies Program in Production Engineering \\ Dr. Bacelar 1212, 04026-002 São Paulo, Brazil \\ betomendesreis@msn.com.br, \\ sivateixeira@yahoo.com.br, \\ politeleia@uol.com.br, \\ irenilza@gmail.com
}

\begin{abstract}
Product Life Cycle (PLC) has been used to analyze the behavior of a product during its time of production. The success of enterprises depends on its capacity of aligning Supply Chain Strategy (SCS) with PLC. The purpose of this work was to develop a model to align the right SCS with PLC stage. This research shows three case studies and results provides that different companies used diverse approaches on managing life cycle of its products. However, they were successful in reaching competitive advantage due to correct alignment between SCS with PLC.
\end{abstract}

Keywords: Agile Supply Chain, Responsive Supply Chain, Flexible Supply Chain, Lean Supply Chain.

\section{Introduction}

The results of a company are connected directly to the adopted strategy. An enterprise may aspire total quality of its products, but if it uses an aggressive cost reduction strategy, may not achieve the desired result. In fact, it is fundamental to an organization to align market, production and business strategy to reach its goals.

First of all, strategies of enterprise must be established considering the Product Life Cycle (PLC) [1] and its correct alignment with strategy of Supply Chain Management 2]. Nowadays, we consider that SCM has four strategy approaches: lean, flexible, responsive and agile [3. These strategies are known as an evolution of manufacturing strategy thinking. For this reason, when a company applies a manufacture strategy, this strategy extends all along the supply chain.

This paper aims to analyze the relevance of aligning Supply Chain Strategy (SCS) with Product Life Cycle and the consequences for the companies. 


\section{Theoretical Background}

\subsection{Supply Chain Strategies}

In order to understand the Supply Chain Management Strategies, four approaches were defined [2]:

Lean Supply Chain (LSC) focus on major productivity with cost reduction, through the elimination of wastes 4 .

Flexible Supply Chain (FSC) flexible behavior of system. Involves equipments, workforce and transportation network. The main types of flexibility are represented by the flexibilization of the production systems [5].

Responsive Supply Chain (RSC) corresponds the capacity of response to market needs, considering time and cost. [6].

Agile Supply Chain (ASC) involves the capacity of introducing new products to supply new markets. Agility is the capability of a company to structure the business process in order to answer the new clients' requirements and wishes [7].

Each one of these strategies needs to align with demand and supply characteristics. And it is considered whether the product is innovative or functional [2, 3] and [8].

\subsection{Product Life Cycle}

PLC may be defined as the process of existence of a product since its idea and development until its recycling [1]. In this process, the product passes through different stages, such as demand analysis, conception, manufacturing, test, execution, evaluation, maintenance and discard $[9$. PLC deals with the evolution of a chain product, that may occur in two ways: a) the creation of a new product in the market, and b) referring to mature products that there are already in the market [1. The PLC function shows four clear stages: introduction, growth, maturity and decline [10].

\section{Methodology}

This article includes the proposition of a model aiming to explain the relation between PLC and SCS and the performance of case studies to check the pertinence of the model in real industrial conditions. To do so, this study was conducted based on these steps:

1. A literature review regarding the concepts of PLC and SCS;

2. Development of model based in Literature Review, using authors such as [1, [2], 8], 9], 10] and [11;

3. Three case studies were realized using public data, annual management reports of companies, interviews and informations published in the last 30 years;

4. Discussion of the cases considering the data collected and the model proposed. 


\section{Developing a Model to Align Supply Chain Strategy and Product Life Cycle}

To develop a model that represents SCS with PLC, the authors analyzed different contributions in the theme [1], [2, 8, ,9, 10] and 11, resulting the model shown in Figure 1.

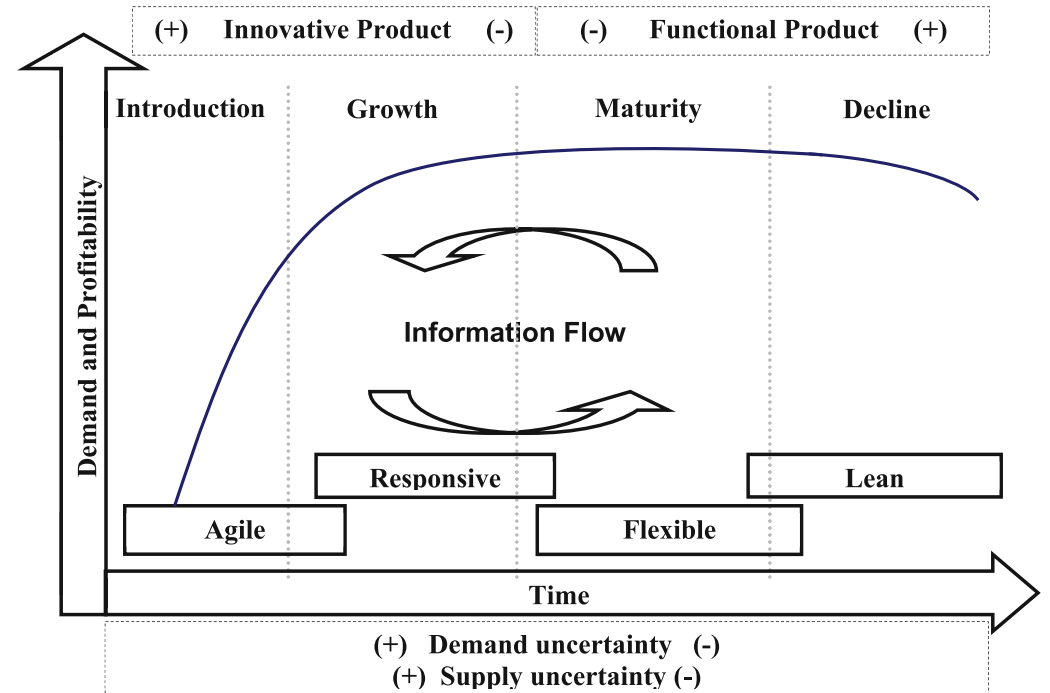

Fig. 1. Proposed Model

To explain Figure 1, it is necessary to study PLC through its four stages:

Introduction: represents launching the product in the market. The product is considered innovative, with high profit margins and no competitors. According to different studies, a product needs to comply with some criteria, to be considered innovative [2], 3] and [8. However, in this scenario, there is high demand uncertainty, because it is not know how consumers react to new products. On the introduction stage a high supply uncertainty occurs due to the difficulty in finding suppliers.

In addition, the more applicable SCS in this context is Agile Supply Chain [2] and [8].

Growth: in this stage, on similar products are put in the market and consumers begin to have options. Competitors develop copies of the product at lower prices, reducing profit margin. However, supply uncertainty starts to reduce, because new suppliers arise. Now the chain perspective is responsiveness, which means to attend clients requirements faster. On the other hand, the enterprise needs to reduce manufacturing and distribution costs. This stage allows new opportunities to reach competitive advantage [12]. 
On Growths phase, for a short time period, companies that adopt agile supply chain or responsive supply chain strategies may compete. However, the enterprise that launches a product must decide if it should change its strategy to responsiveness, or maintain agility and production of that item. In doing so, it does not no represent that PLC product is over, because the company may license the product for manufacturing to other enterprises in different countries. Meanwhile, there are companies that keep manufacturing similar products.

Maturity: at this stage, the product is definitively established in the market and starts the transition from innovative to functional. Organizations have knowledge about demand, so demand uncertainty is reduced, whereas supply uncertainty rises due to competition for resources among producers.

Another condition that affects companies is brought by the costumers, who do not accept failures in products on the maturity stage, and also do not pay more for these products [12]. As competition and supply uncertainties are high and demand is divided among the players, the best way to react is using flexibility in supply chain strategy.

In this scenario, profit tend to establish or decrease, and companies need decide weather to adopt Flexible Supply Chain Strategy to hold in this segment; come back to the previuos stages and launch new producs; or stay in the responsive segment (growth).

Decline: when products reach this phase, the enterprise knows the market, suppliers and competitors. Uncertainty of demand and suppliers decrease to a very low level. Some companies leave the market.

In this context, companies need to embrace a Lean Supply Chain Strategy. They must reduce wastes in the supply chain nodes, to ensure the feasibility of selling the products [13]. Of course, much has been discussed about lean manufacturing after the work of Womack and Jones [13] and the relationship between agility and lean approach [4], but in this research the focus is put on the relation between the decline stage and lean supply chain strategy.

\section{Case Studies}

The alignment between PLC and SCS is an opportunity for enterprises to obtain success in their markets. To illustrate this, three case studies are presented, related to the model proposed in this paper.

\subsection{FIAT}

The Italian Automobile Factory Torino (FIAT) arrived in Brazil in the 70's. After a difficult period, with a lot of questions about quality of its products, the enterprise became the biggest company in selling vehicles for the last twenty years in Brazil.

A reason for this success was the launching of a small vehicle called Uno (one). It was showed for the first time in 1983 and started to be produced in Brazil in 
1984. The innovative car got immediate success. Until 1988 the firm sold three millions of these cars in the world [14.

In Brazil, the car spreads in the streets and its production increases with the rise of the so called 'popular cars', in the beginning of the 90's. This kind of vehicle consisted of compact cars without some safety items and comfortable equipments, but with an attractive price. Brazilian government established the price of the popular car in 7.350 american dollars 15. This was interesting for the people and for the producers, since Brazilian currency had parity with the dollar from 1994 to 1999.

Afterwards, the Brazilian scenario of vehicle production changed and popular cars received many versions with different prices. Actually, a car considered popular, without air conditioning and electric power steering costs 10.200 dollars [16.

In the 90's, the opening of the market by the Brazilian government, caused an invasion of many companies. Firms like Renault, Honda and Hyundai changed the national market and became a concern to the four local automobile factories previously installed in the country, Volkswagen, Fiat, Ford and General Motors. So, Fiat was forced to launch new models, while maintaining its major success. For that, the company changed the name Uno to Mille, readjusting the car in the market. The name represents an analogy with the engine that had a cylinder capacity to 1.000 cubic metric centimeters.

Some years ago, Fiat introduced a vehicle called 'New Uno', but it was a totally new product with new lines and another concept. However, the Mille was produced until 2013, when, with legislation change in Brazil, its production became unfeasible. The problem was the impossibility of including airbag systems and ABS brake in the project, an obligation for vehicles produced in Brazil since 2014 .

When we analyzed Fiat SCS linked to PLC, the model connects perfectly with the case Fiat Uno/Mille. When Fiat launched Uno in Brazilian market, the vehicle changed the paradigm of car production, creating one of the products with longest longevity of the country. This allowed to the company an immense return of investment along thirty years of production.

The Uno's success made competitors enter in the segment with models like Gol (Volkswagen), Chevette (General Motors) and Escort (Ford). As a result, Fiat needed to adequate itself to answer new market challenges and establish a Responsive Supply Chain strategy. To do this, the company launched many different products, such as the sedan Premio, Station wagon Elba, and sporting models of Uno. The increase of consumption in Brazil, motivated by economic stability, made the Brazilian market very attractive and concurrent. This fact also made the company change its strategy to a Flexible Supply Chain, as a reaction to a scenario of maturity for the product and segment. In doing so, Fiat assembly lines became more flexible to produce different kind of products. Suppliers oriented their stocks and production to supply Fiat according to factory programmation. 
In the XXI century, the major objective of the firm was to make Mille the cheapest car in the country, so the company needed to reduce costs and wastes. With this aim, Fiat applied the Lean Supply Chain strategy, with the purpose to maintain the product competitive in the market.

\subsection{Apple}

Apple is a company known around the globe and its founder, Steve Jobs, is the image of tireless search for better results and a shining mind capable of creating innovations constantly, characteristics that built a very profitable company even after Jobs' death. Innovative products have a natural uncertainty of demand and supply, due to the uncertain supplier capacity to respond to all the requirements of the new products.

Authors argue that innovative products have a short PLC [10], [14]. However, when we analyze for instance, the longevity of battery radios, it may be seen that this is not an absolute truth. What happens is that some products, even when its inventor loses interest in production, are still produced by many other firms, and although this is a way of survive, these producers are not entitled to ask for patents.

An enterprise in constant innovation process has its image connected to this performance and, in doing so, maintains high profitability margins. In this case, we can infer that Apple used an opposite strategy than Fiat. The company kept itself in an innovative way and established an Agile Supply Chain Strategy. For example, the IPAD [17, the tablet of 10 inch launched in 2010, may be considered a reference Very quickly it became a successful innovation by Apple. So this market called attention of enterprises like Samsung, that launchedan concurrent tablet called Galaxy to dispute in this new market. The evolution of products in PLC context required Apple to decide between applying an Agile Supply Chain Strategy or change its strategy to Responsive Supply Chain. The decision is clearly known; the company opted to continue with innovation of its products and maintain an Agile Supply Chain Strategy.

In 2011, Apple launched IPAD II and started the PLC of a new product. Despite the exterior similarity of the products, in conception they are really completely different. The demand for these new tablets did not prevent its previous generation's demand. In fact, there are a lot of people in the world that want to be inserted in a technologicalogic market, but have not money enough to pay for the products. For this reason, some enterprises keep on producing items of ancient generation and extend its PLC to the following stages using Flexible and Lean Supply Chain Strategies. Many Chinese companies are acting in this segment. Meanwhile, Apple continues its process of creating and innovating. The IPAD is now in the fifth version.

\section{$5.3 \quad$ Intel}

The North American company Intel was founded in 1960. This company embraced a hybrid strategy between Fiat and Apple. The firm was the first bigger 
processors manufacturing in the world and is not the only one, because it did not establish patents for its products in the 286, 386 and 486 versions. These processors were copied by other companies using reverse engineering.

In 1993 Intel launched the Pentium Processor, which started a new era of processors, adding value to the brand and changing competition scenario [18. The product followed the same PLC of IPAD in Apple, however in a slower way. The company adopted an Agile Supply Chain Strategy, and although it continued to create innovative products, it realized that it could establish different strategies to processors.

The company understood that its products were really good for a significant part of world population. Many people use computer for simple things, such as to send an email, type a text or make a calculation, and they do not need a modern processor. With this idea in mind, the company perceived that it could launch a new processor, while maintaining the old one.

Different from the Apple case, competition in manufacturing processors is very limited, only two players respond to major demand around the world. So when Intel launched Pentium II in 1997 [18, it decided to keep two lines of products with the same main name. However, this was not good for its business image, because Intel was a technology and innovative company. The image of an innovative company is not in agreement with the dichotomy high technologies and old product altogether, because consumers see this as a second category product, an item not 'so good enough'. So, in 1998 Intel launched a new generation of processors, the ,Celeron'.

Indeed, Celeron line was a Pentium I in a new format with some modifications. The negative image of using a second line product was substituted by the pleasant image of an economic and efficient processor. In doing so, the company was able to prolong PLC cycle and apply different supply chain strategies without harming the brand. So, Intel could adopt the Agile Supply Chain Strategy to new products of Pentium line and a different Responsive Strategy to the Celeron line.

The strategy reduced risks of stolen technology, and as a result, Intel is nowadays the major processors producer of the world and continues with innovation processes in many other types of processors and brands.

\section{Conclusion}

This paper deals with the alignment between SCS and PLC. A model was proposed and discussed in practice, through three case studies with different kind of enterprises. Our analysis indicates that these firms used different approaches to the strategies and alignments with good results. However, it may be considered that, in all cases, the profitability of the companies was related with adequate alignment between SCS and PLC.

Despite of the results presented in this paper, new studies in other companies shall be conducted to better validate the model. So, the next steps of this research is to analyze other companies using the proposed model. 
This is an interesting and very present discussion, which does not finish with the examples here presented. The authors remain in the research of the problems referent to supply chain aspects, and will be glad there are other persons interested in interacting with them on these issues.

\section{References}

1. Tang, X., Yun, H.: Data model for quality in product lifecycle. Computers in Industry 59, 167-179 (2008)

2. dos Reis, J.G.M., de Oliveira Costa Neto, P.L.: Method for quality appraisal in supply networks. In: Emmanouilidis, C., Taisch, M., Kiritsis, D. (eds.) Advances in Production Management Systems, Part II. IFIP Advances in Information and Communication Technology, vol. 398, pp. 519-526. Springer, Heidelberg (2013)

3. Lee, H.L.: Aligning supply chain strategies with product uncertainties. California Management Review 44(3), 105-119 (2002)

4. Stratton, R., Warburton, R.D.H.: The strategic integration of agile and lean supply. Supply Chain Management 85(2), 183-198 (2003)

5. Sanchez, A.M., Perez, M.P.: Supply chain flexibility and firm performance: A conceptual model and empirical study in the automotive industry. International Journal of Operations \& Production Management 25(7), 681-700 (2005)

6. Gunasekaran, A., Lai, K.: Responsive supply chain: A competitive strategy in a networked economy. Special Issue on Logistics: New Perspectives and Challenges 36(4), 549-564 (2008)

7. Pandey, V., Garg, S.: Analysis of interaction among the enablers of agility in supply chain. Journal of Advances in Management Research 6(1), 99-114 (2009)

8. Fisher, M.: What is the right supply chain for your product? Harvard Business Review 75(2) (1997)

9. Xiao, S., Xudong, C., Li, Z., Guanghong, G.: Modeling framework for product lifecycle information. Modeling and Simulation for Complex System Development 18(8), 1080-1091 (2010)

10. Kotler, P., Armstrong, G.: Principles of Marketing, 12th edn. PrenticeHalll (February 2007)

11. Mahapatra, S.K., Das, A., Narasimhan, R.: A contingent theory of supplier management initiatives: Effects of competitive intensity and product life cycle. Journal of Operations Management 30(5), 406-422 (2012)

12. Christopher, M.: Logistica e o gerenciamento da cadeia de suprimentos, 3rd edn. Cengage Learning, Sao Paulo (2011)

13. Womack, J., Jones, D., Roos, D.: The Machine That Changed the World: The Story of Lean Production. Harper Perennial (1991)

14. Car and Driver, http://caranddriverbrasil.uol.com.br

15. Carplace, http://carplace.virgula.uol.com.br

16. Auto Esporte, http://revistaautoesporte.globo.com

17. Apple, http://www .apple.com

18. Intel, http://www.intel.com 